\title{
THE EFFECTS OF HUMAN AMNIOTIC FLUID AND MEMBRANE ON FRACTURE HEALING ON RAT FRACTURE MODEL
}

\author{
INSAN AMNIOTIK SIVISI VE MEMBRANININ SIÇAN KIRIK MODELINDE KIRIK \\ IYYILEŞMESINE ETKILERI
}

\author{
Alper GÜLTEKIN¹ ${ }^{1}$ A. Meriç ÜNAL², Mehtat ÜNLÜ3 ${ }^{3}$, Safa SATOĞLU4, \\ ${ }^{1}$ Derince Research Hospital, Orthopaedics and Traumatology Department, Kocaeli, Turkey \\ ¿ Suleyman Demirel University, Faculty of Medicine, Sports Medicine Department, Isparta, Turkey \\ ${ }^{3}$ Dokuz Eylul University, Faculty of Medicine, Pathology Department, Izmir, Turkey \\ ${ }^{4}$ Dokuz Eylul University, Faculty of Medicine, Orthopaedics and Traumatology Department, Izmir, Turkey
}

Cite this article as: Gültekin A, Unal AM, Unlu M, Satoglu S. The Effects of Human Amniotic Fluid and Membrane on Fracture Healing on Rat Fracture Model. Med J SDU 2020; 27(1): 105-112.

\section{Öz}

\section{Amaç}

İnsan amniotik sıvısı çeşitli büyüme faktörleri ve hyaluronik asit içermektedir. Tendon, sinir ve kemik yaralanmalarının iyileşmesi üzerine pozitif etkiye sahiptir. İnsan amniotik membranı da tendon ve sinir iyileşmesi üzerine etkili olmakla birlikte yanık ve kompleks yaralarda deri iyileşmesi üzerine de pozitif etkiye sahiptir. Çalışmanın hipotezi insan amniotik sıvısı ve insan amniotik membranının kırık iyileşmesini pozitif yönde uyarmasıdır. Çalışmanın amacı, rat tibia kırık modelinde insan amniotik sıvı ve membranının kırık iyileşmesine etkisinin araştırılmasıdır.

\section{Gereç ve Yöntem}

36 erkek Wistar ratın her iki tibiaları kullanılarak 72 açık kırık modeli oluşturuldu ve üç gruba ayrıldı. Grup1 kontrol grubu olarak alındı. Grup-2'de, seronegatif gebelerin ikinci trimesterde yapılan amniosentezlerinden alınan insan amniotik sıvısı kırık bölgesine enjekte edildi. Grup-3'te ise seronegatif term gebelerin sezaryanları sonrası alınan insan amniotik membranı kırık bölgesine sarıldı ve sonrasında insan amniotik sıvı enjeksiyonu yapıldı. Uygulamalar sonrası üçüncü ve altıncı haftalarda radyolojik kırık kaynama paternleri ve Modifiye Lane-Sandhu sınıflaması kullanılarak yapılan histopatolojik ölçümler değerlendirildi.

\section{Bulgular}

Üçüncü hafta sonunda, Grup-2 ve Grup-3'te Grup1'e gore daha iyi histopatolojik sonuçlar elde edildi. Altıncı haftada ise Grup-2'nin sonuçları Grup-1'den daha iyi bulundu. Grup-3'ün de sonuçları Grup-1'den iyi olmakla birlikte istatistiksel olarak anlamlı fark saptanmadı. Üçüncü ve altıncı haftalarda Grup-2'nin histopatolojik skoları Grup-3'ten anlamlı derecede daha iyi bulundu( $p=0.021, p=0.019)$.

\section{Sonuç}

Mevcut sonuçlara gore insan amniotik sıvısının kırık iyileşmesi üzerine pozitif etkisi olmakla birlikte insan amniotik membranının pozitif etkisi saptanamamıştır. Düşük immünitesi ve temin kolaylığı nedeni ile insan amniotik membranı da insan amniotik sıvısı ile kombine bir şekilde kırık iyileşmesinde farklı uygulama teknikleri ile kullanılabilir.

Anahtar Kelimeler : Tibia kırık modeli; insan amniotik sıvısı; insan amniotik membranı; hayvan çalışması; kırık iyileşmesi

\section{Abstract}

\section{Objective}

Human amniotic fluid contains several growth factors and hyaluronic acid. It has positive effect in healing

İletişim kurulacak yazar/Corresponding author: abdmunal@yahoo.com

Müracaat tarihi/Application Date: 11.02.2019 • Kabul tarihi/Accepted Date: 15.04.2019

Available online at http://dergipark.gov.tr/sdutfd

Makaleye http://dergipark.gov.tr/sdutfd web sayfasından ulaşılabilir. 
the tendon, nerve and bone injuries. Human amniotic membrane has positive effects on tendon, nerve healing and is also used for skin healing in burns and complex wounds. We hypothesized that human amniotic fluid and human amniotic membrane have positive stimulating effects on fracture healing. The aim of this study is to investigate the effects of human amniotic fluid and human amniotic membrane on bone healing in rat tibial bone fracture model.

\section{Materials and Methods}

A 72 open fracture model was created for both tibial bones of 36 male Wistar rats. They were divided into three groups. Group-1 was the control group. In Group-2, human amniotic fluid which was taken from amniocentesis of seronegative pregnants in their second trimester was injected to the fracture site. In group-3, human amniotic membrane which was taken from normal seronegative term pregnants after their caesarean sections was wrapped around fracture site and then human amniotic fluid was injected to the fracture site. Radiological fracture union patterns and histopathological evaluations with Modified Lane-Sandhu classification were performed with Modi- fied Lane-Sandhu classification at the end of third and sixth weeks.

\section{Results}

At third week, Group-2 and Group-3 had better histopathological results than Group-1. At sixth week, Group-2 had significantly better results than Group-1. Group-3 had also better results than Group-1 although there was no statistical significance. At third and sixth weeks, histopathological scores of Group-2 were significantly better than Group-3( $p=0.021, p=0.019)$.

\section{Conclusion}

Our data suggested that human amniotic fluid had positive effect itself but with human amniotic membrane, it had no positive effect on bone healing. With its low immunity and easy delivery, human amniotic membrane can also be used to stimulate bone healing in combination with human amniotic fluid with different application techniques.

Keywords: Tibia fracture model, human amniotic fluid, human amniotic membrane, animal study, fracture healing

\section{Introduction}

Bone fractures are common conditions that can affect the whole population. Besides bony involvement, surrounded soft tissues are also affected from fracture. Fracture healing is a specialized type of wound healing and results in a complex condition with involvement of cellular and biochemical processes(1). These processes may be affected positively or negatively from many factors. Fracture healing occurs close to original anatomical and functional properties of bone without scar tissue with conservative or surgical treatment modalities. Besides these treatment methods, in up to $10 \%$ of all fractures, union problems may be seen(2). Factors that enhance bone healing and accelerate fracture union are still investigated.

It is known that human amniotic fluid (HAF) which is taken at second trimester has high levels of growth factors including fibroblast growth factor(FGF), insulin like growth factor I and II(IGF-I and IGF-II) and epidermal growth factor(EGF) and molecules like chondroitin 4- and 6-sulfate, dermatan sulfate and heparan sulfate(3). Besides these, it also contains high levels of hyaluronic $\operatorname{acid}(\mathrm{HA})$ and hyaluronic acid stimulating activators $(\mathrm{HASA})(4,5,6)$. HASA stimulates HA release and provides bone healing with remodelation(7). HA, alone or with growth factors, was studied to enhance bone healing on animal fracture models(8). It was demonstrated that human amniotic fluid lowers scar formation and enhances tissue healing by increasing the HA levels at wound tissue(9).

Human amniotic membrane(HAM) is the inner layer of fetal membranes and in contact with amniotic fluid. It is still used in treatment of resistant skin ulcers and it was shown experimentally that it has had positive effects on nerve and tendon healing $(10,11)$. It may also be used for burns and complex wounds(12). HAM has found extensive application areas especially in ophthalmology $(13,14)$. It also has very low immunity and may be used as a transportation matrix(12).

We hypothesized that HAF itself and with HAM have positive stimulating effects on fracture healing. The aim of this study is to investigate the effects of HAF and HAM on bone healing in rat tibia fracture model.

\section{Materials and Methods}

\section{Animals}

Ethical committee approval was taken from Dokuz Eylul University (DEU) Experimental Animal Research Ethical Committee. Study was made in DEU Experimental Animals Research Laboratory. Seventy-two tibial bones of 36 Wistar rats which had a 
weight of 250 to $300 \mathrm{gr}$ were included in the study. Before starting the experiment, the animals were kept at standard laboratory conditions (12-hour day - 12hour night cycle, 20-22 0C room temperature and 50$60 \%$ humidity) for one week. Enough food and water was provided.

\section{Amniotic Fluid Collection}

DEU Clinical Studies Ethical Committee approval was taken. HAFs were collected from amniocentesis of seronegative pregnants in their second trimester (16-24 weeks of pregnancy). Collected material was kept at -20 OC and used immediately $(9,16,17)$.

\section{Amniotic Membrane Preparation}

HAMs were taken from normal seronegative term pregnant women after their caesarean sections. Amniotic epithelia was dissected from chorion layer. HAMs were washed with sterile isotonic saline solutions to remove all blood, kept in $10 \%$ gentamicin sulfate solution at +4 OC and used in four hours(10)(Figure-1).

\section{Study Design}

All 36 rats were operated bilaterally and both tibias of all rats were included in the study. All 72 tibial bones underwent the same standard surgical procedure. Three groups were created and 12 rats (24 tibias) were included in each group. In the first group, only surgical procedure was performed without any extra approach and named as control group(C group). For the second group, same surgical procedure and one $0,3 \mathrm{ml}$ single dose local HAF were applied to HAF group(3). Lastly for the third group, same surgical procedure, prepared HAM(wrapped 3600 over the fracture site and fixed with number 5,0 Vicryl sutures)

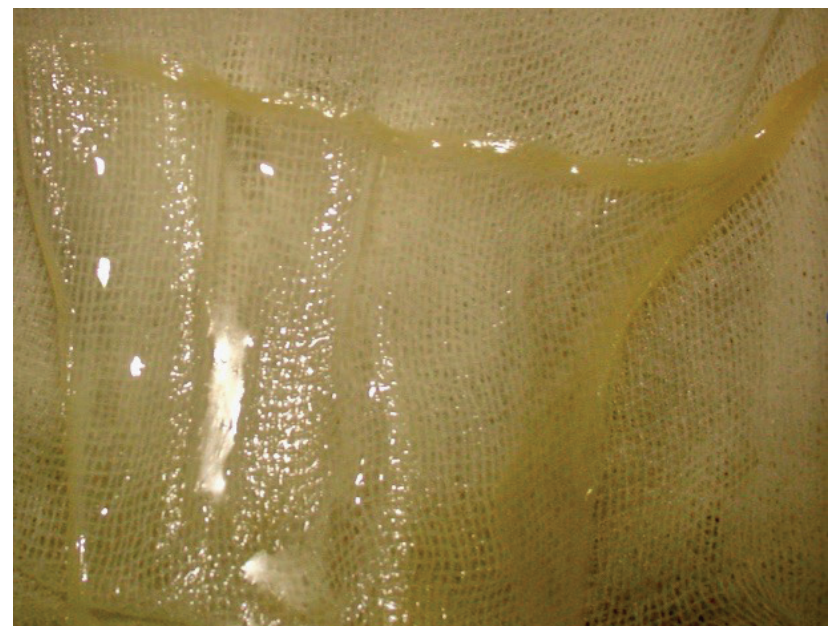

Figure 1. Prepared HAM, just before using and $0,3 \mathrm{ml}$ single dose local HAF injection were applied to HAM+HAF group.

\section{Operative Procedure}

A dose of $80 \mathrm{mg} / \mathrm{kg}$ intraperitoneal ketamine(Ketalar, Eczacıbaşı, Luleburgaz, Turkey) was administered to animals for general anesthesia. Anterior side of cruris from knee to ankle was shaved. Operative site was sterilized with Batticon. Skin and subcutaneous tissue of anterior cruris were passed through and muscles and periosteum was sharply dissected. A transverse fracture line was produced with a cutting motor. For intramedullary fixation of fracture, a $20 \mathrm{G}(0,9 \mathrm{~mm})$ injector needle was used from knee to ankle. After the control of stability of fixation, fascia and skin was closed with 5,0 number Vicryl and 4,0 number Prolene, respectively(Figure-2).

Fifty $\mathrm{mg} / \mathrm{kg}$ single dose of first generation cephalosporin (Cefazolin Sodium) were administered to all animals. Same antibiotherapy was sustained for postoperative two days at $50 \mathrm{mg} / \mathrm{kg} /$ day dose. Splints were not used postoperatively; all animals were allowed full weight bearing immediate.

\section{Radiological Evaluation}

Just after sacrification, direct radiographies of all tibias were taken. Bone union rates and callus formations were observed. No quantitative method was used for radiological evaluation.

\section{Histopathological Evaluation}

Out of 66 tibial bones, 34 and 32 were evaluated histopathologically at the end of third week and sixth week, respectively.

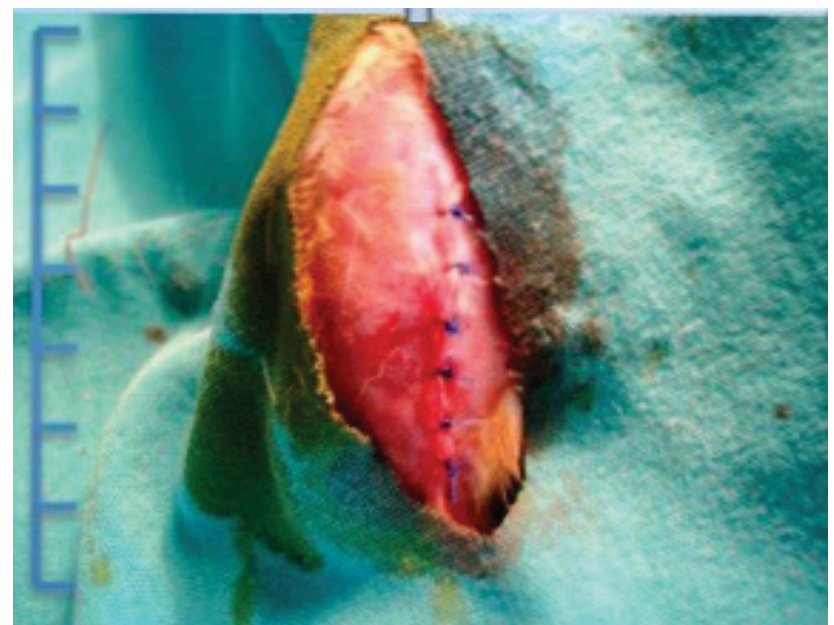

Figure 2. Early postoperative period 
All bones were cleaned from soft tissues and only the tibial bones were kept in 10\% formalin solution for 48 hours. Then, all tibial bones were decalcified at $10 \%$ formic acid solution for three days. Decalcified tibias were subjected to dehydration, translucency and parafinization processes in autotechnicone and embedded in paraffin for blocking. Five micrometer thick slices were prepared close to the center of callus perpendicular to fracture line. All slices were painted with hematoxylin-eosin dye and examined with a polarized light microscope on $x 4$ and x10 magnifications(Figure-3 and Figure-4).

Modified Lane-Sandhu histological scoring scale was used for histological evaluation(18). In this scoring system, proximal union, distal union, spongy bone, cortex and bone marrow were examined separately(Table-1).

\section{Statistical Analysis}

SPSS (version 11.0 for Windows, Chicago, IL, USA) was used for data analysis. Comparison of histopathological scores between groups was performed with Mann Whitney $U$ test. Comparison between third and sixth week data was made with Wilcoxon test.

\section{Results}

During the study period, one animal had wound site infection(in HAF group), one had loss of reduction of both tibias(in HAM+HAF group) and one found dead in his cage(in HAF group). These complications were considered as normal complications of the surgical procedure. All these three animals were excluded from the study. All animals were sacrified at the end of third and sixth week with high dose ether(3).
A

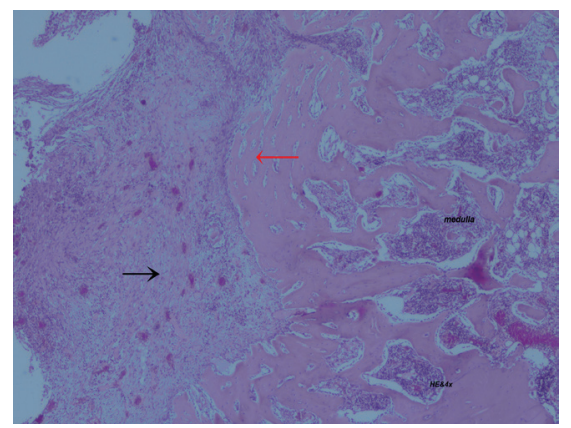

$B$

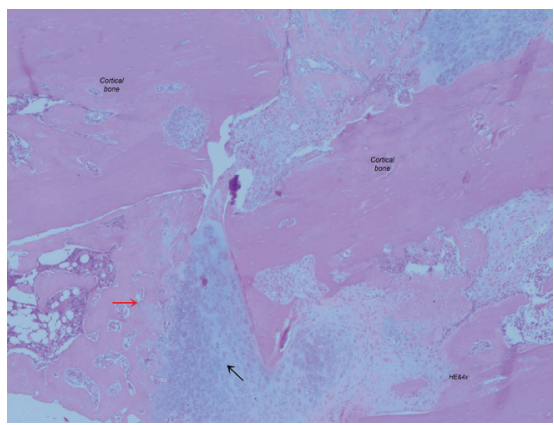

C

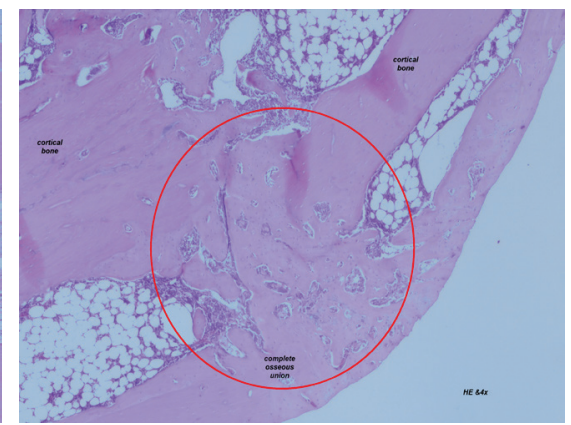

Figure 3. Histopathological samples.

A: $x 4$ magnification of fibrous union sample. Red arrow: Cortical bone. Black arrow: Fibrous tissue

B: x4 magnification of osteochondral union sample. Red arrow: New bone formation. Black arrow: Chondral formation

C: $x 4$ magnification of bone union sample

A

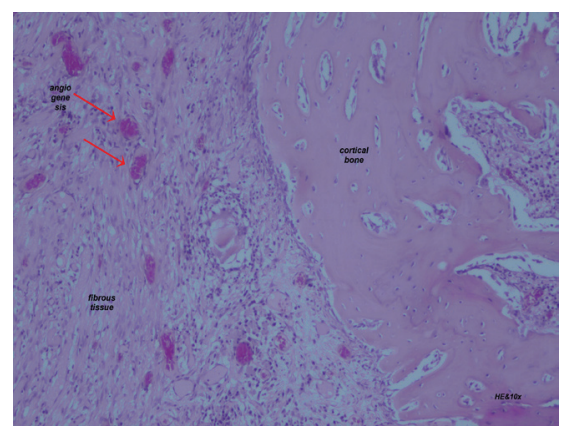

B

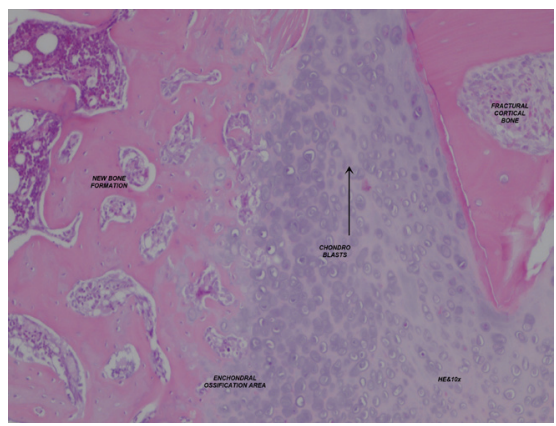

C

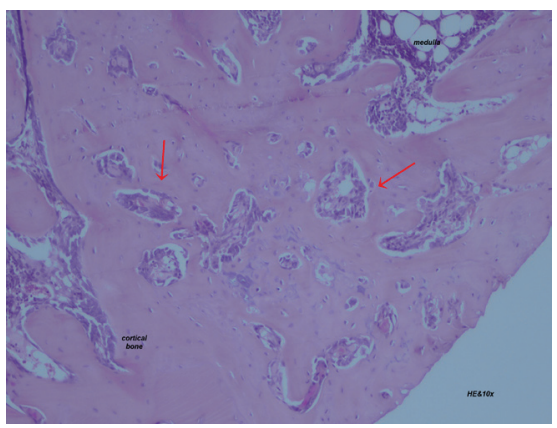

Figure 4. Histopathological samples.

A: x10 magnification of fibrous union sample,

B: $\times 10$ magnification of osteochondral union sample,

C: $\times 10$ magnification of bone union sample 
In comparison of third and sixth week histopathological scores of $\mathrm{C}$ group, sixth week scores were better but there was no statistical significance $(p=0.937)$. Sixth week histopathological scores of HAF and HAF+HAM group were significantly better than third week scores( $p=0.037, p=0.041$ respectively) (Table-2).

Third week histopathological scores of all groups were compared to each other. HAF group scores were better than $\mathrm{C}$ group but there was no statistical significance $(p=0.63)$. HAF+HAM group scores were also better than $\mathrm{C}$ group, there was also no statistical significance $(p=0.123)$. HAF group was found significantly better than HAF+HAM group(0.021)(Table-3).

Sixth week histopathological scores of all groups were compared to each other. HAF group scores were significantly better than $\mathrm{C}$ group $(\mathrm{p}=0.036)$. HAF+HAM group scores were also better than $C$ group, there was also no statistical significance $(p=0.418)$. HAF group was found significantly better than HAF+HAM group(0.019) (Table-4).

Upon radiological evaluation at third week, partial bridging dominancy was observed. Only six tibias had full bridging (two were in $\mathrm{C}$ group, three and one were in HAF and HAF+HAM groups respectively). There was no bridging observed in four tibias(two were in C group, one in HAF group and one in HAF+HAM group). There was no remodelation seen in any of tibias at third week evaluation.

Upon radiological evaluation at sixth week, full bridging dominancy was found. There was no bridging seen in only two tibias(one was in $C$ group, one in HAF+HAM group). Fracture lines disappeared in C and HAF groups; however, lines were apparent in HAF+HAM group.

\begin{tabular}{|c|c|c|}
\hline Union & No evidence of union & 0 \\
\hline \multirow[t]{4}{*}{ Proximal/Distal } & Fibrous union & 1 \\
\hline & Osteochondral union & 2 \\
\hline & Bone union & 3 \\
\hline & Complete organization of shaft & 4 \\
\hline \multirow[t]{5}{*}{ Cancellous bone } & No osseous cellular activity & 0 \\
\hline & Early apposition of new bone & 1 \\
\hline & Active apposition of new bone & 2 \\
\hline & Reorganizing cancellous bone & 3 \\
\hline & Complete reorganization of cancellous bone & 4 \\
\hline \multirow[t]{5}{*}{ Cortical bone } & Non & 0 \\
\hline & Early appearance & 1 \\
\hline & Formation under way & 2 \\
\hline & Mostly reorganized & 3 \\
\hline & Completely formed & 4 \\
\hline \multirow[t]{5}{*}{ Marrow } & None in resected area & 0 \\
\hline & Beginning to appear & 1 \\
\hline & Present in more than half of the defect & 2 \\
\hline & Complete colonization by red marrow & 3 \\
\hline & Mature fatty marrow & 4 \\
\hline \multirow[t]{5}{*}{ Total points possible per category } & Proximal union & 4 \\
\hline & Distal union & 4 \\
\hline & Cancellous bone & 4 \\
\hline & Cortex & 4 \\
\hline & Marrow & 4 \\
\hline Maximum score & & 20 \\
\hline
\end{tabular}




\begin{tabular}{|l|l|l|l|}
\hline & Third week & Sixth week & p values \\
\hline C Group & $8,83 \pm 2,33$ & $9,58 \pm 4,29$ & 0,94 \\
\hline HAF Group & $9,75 \pm 2,9$ & $13,8 \pm 3,71$ & 0,03 \\
\hline HAM+HAF Group & $7,5 \pm 1,65$ & $10,1 \pm 1,91$ & 0,04 \\
\hline
\end{tabular}

The relationship within the groups were assessed by Wilcoxon test.

\begin{tabular}{|l|l|l|l|l|l|l|}
\hline \multicolumn{3}{|l}{ C Group } & \multicolumn{2}{l|}{ HAF Group } & \multicolumn{2}{l|}{ HAM+HAF Group } \\
\hline & mean & $\mathbf{p}$ value & mean & p value & mean & p value \\
\hline HPS & $8,83 \pm 2,33$ & & $9,75 \pm 2,9 a$ & a: 0,63 & $7,5 \pm 1,65^{\mathrm{b}, \mathrm{c}}$ & $\mathrm{b}: 0,12$ \\
& & & & & & \\
c:0,02
\end{tabular}

a: HAF group compared to $C$ group, b: HAM+HAF group compared to $C$ group, c: HAM+HAF group compared to HAF group. Values are presented as means $\pm S D$. The relationship between groups was assessed by Mann Whitney $U$ test.

\begin{tabular}{|l|l|l|l|l|l|l|}
\hline \multicolumn{3}{|l}{ C Group } & \multicolumn{2}{l|}{ HAF Group } & \multicolumn{2}{l|}{ HAM+HAF Group } \\
\hline & mean & $\mathbf{p}$ value & mean & p value & mean & p value \\
\hline HPS & $9,58 \pm 4,29$ & & $13,8 \pm 3,71 \mathrm{a}$ & a: 0,03 & $10,1 \pm 1,91^{\mathrm{b}, \mathrm{c}}$ & b: 0,42 \\
& & & & & & C: 0,01 \\
\hline
\end{tabular}

a: HAF group compared to $C$ group, b: HAM+HAF group compared to $C$ group, c: HAM+HAF group compared to HAF group. Values are presented as means $\pm S D$. The relationship between groups was assessed by Mann Whitney $\mathrm{U}$ test.

\section{Discussion}

We prefer open osteotomy techniques to create the fracture model because there is a tendency to delayed or non-union in open fractures and this open model was thought to be a better model to show the effectivity of our treatment(15). Open technique also allowed to perform HAM to the fracture site. Intramedullary fixation was preferred to provide callus formation and secondary bone healing.

Human amniotic fluid was used as single dose local injection to fracture site as described in literature previously(3). HAF group had better results compared to control group both at third and sixth week evaluation. HAF application may have accelerated fracture union according to these results. This positive effect of HAF was dependent to its high HA, HASA and growth factor content. It also increases endogenous and exogenous HA.

There are several studies that support positive effects of HAF application. Huang et al. found in their animal study that high molecular weight HA stimulates osteoblastic differentiation(8). Aslan et al. created a bone defect and filled this defect with graft, HA combination and found better results with graft, HA combination on bone healing at the end of six weeks(19). Radomsky et al. used HA and Fibroblast growth factor-2 with single dose local injection to fracture site in their animal fracture model and found a callus formation stimulation with this application(20). Eckardt et al. also used $\mathrm{HA}$ and rhBMP-2 with single dose local injection and 
found positive results in fracture healing(21). Kerimoglu et al. used HAF that was obtained in two different weeks of gestation and found better results on bone healing with second trimester $\operatorname{HAF}(3)$.

Human amniotic membrane had successful results in medical usage, including growth factors and being used as transportation matrix $(22,23,24,25)$. Due to these factors, a new group was created to include HAM and HAF together. Better results were expected with combined usage, but compared to single dose, local injection of HAF provided better results on bone healing.

Besides positive effects of HAM in the literature, HAF+HAM group also could not provide significantly better results on $\mathrm{C}$ group. In several studies it was found that surrounding soft tissues act as cell source for bone healing $(26,27)$. It was thought that HAM acts as an effective mechanical barrier and blocks interaction of bone with surrounding soft tissues which may cause delayed healing. Utvag et al. used in their animal fracture model study a surgical mesh to investigate its effect on bone healing and found that surgical mesh negatively affects bone healing(27). HAM has also acted as mechanical barrier like surgical mesh in our study. Besides its high content of growth factors, HAM blocks cell migration from surrounding soft tissues and also blocks interaction of injected HAF. Its own growth factors were not enough to stimulate bone healing. Its mechanical barrier feature may positively affect tendon and nerve adhesions but not bone healing $(9,10)$.

In radiological evaluation there was no gross difference between groups. No significant quantitative parameter was found in the literature so quantitative evaluation was not performed. Radiological evaluation was performed to support histopathological evaluation.

There are some limitations in our study. Quantitative radiological evaluation was not conducted. Quantitative analysis with microtomography or bone mineral density may be performed with planning their cost. For histopathological evaluation, only hematolxylane-eosine dye was used. Histomorphometric and immunohistochemical methods may be used in future studies. Polarized light microscope was used in our study, on the other hand electron microscope may give more detailed information about bone healing.

\section{Conclusion}

Different treatment methods to enhance bone healing were studied. In our study, after single dose local injection of HAF, early bone healing stimulation was observed. No positive effect was determined with HAM on bone healing. Single dose HAF injection is a simple method to enhance healing of tibial bone in rats. Contrary to our results, with its low immunity and easy delivery, HAM may also still be used to stimulate bone healing in combination with HAF with different application techniques. Different application techniques of HAM and HAF are planned for future studies.

\section{References}

1. Rausch V, Seybold D, Königshausen M, Köller M, Schildhauer TA, Geßmann J. Basic principles of fracture healing. Orthopade. 2017 Aug;46(8):640-7

2. Zura R, Xiong Z, Einhorn T, Watson JT, Ostrum RF, Prayson MJ, Della Rocca GJ, Mehta S, McKinley T, Wang Z, Steen RG. Epidemiology of fracture nonunion in 18 human bones. JAMA Surg. 2016 Nov 16; 151(11): e162775

3. Kerimoglu S, Livaoglu M, Sonmez B, Yulug E, Aynacı O, Topbas M, Yarar S. Effects of Human Amniotic Fluid on Fracture Healing in Rat Tibia. J. of Surg Res 2008: 152, 281-7

4. Dahl LB, Kimpton WG, Cahill RNP, Brown TJ, Fraser JRE. The origin and fate of hyaluronan in amniotic fluid. J Dev Physiol. 1989; 12:209-18

5. Longaker MT, Adzick NS, Hall JL, Stair SE, Crombleholme TM, Duncan BW, Bradley SM, Harrison MR, Stern R: Studies in fetal wound healing, VII. Fetal wound healing may be modulated by hyaluronic acid stimulating activity in amniotic fluid. J Pediatr Surg. 1990 Apr;25(4):430-3.

6. Longaker MT, Adzick NS: The biology of fetal wound healing: a review. Plast Reconstr Surg. 1991 Apr;87(4):788-98.

7. Longaker MT, Chiu ES, Harrison MR, Crombleholme TM, Langer JC, Duncan BW,Adzick NS, Verrier ED, Stern R: Studies in fetal wound healing. IV. Hyaluronic acid-stimulating activity distinguishes fetal wound fluid from adult wound fluid. Ann Surg. 1989 Nov;210(5):667-72.

8. Huang L, Cheng YY, Koo PL, Lee KM, Qin L, Cheng JC, Kumta SM. The effect of hyaluronan on osteoblast proliferation and differentiation in rat calvarial-derived cell cultures.Journal of Biomedical Materials Research 2003;66(4):880-84

9. Ozgenel GY, Samli B, Ozcan M: Effects of human amniotic fluid on peritendinous adhesion formation and tendon healing after flexor tendon surgery in rabbits. J Hand Surg [Am]. 2001 Mar;26(2):332-9

10. Ozgenel GY, Filiz G: Combined application of human amniotic membrane wrapping and hyaluronic acid injection in epineurectomized rat sciatic nerve. J Reconstr Microsurg. 2004 Feb;20(2):153-7

11. Ozgenel GY: The effects of a combination of hyaluronic and amniotic membrane on the formation of peritendinous adhesions after flexor tendon surgery in chickens. J Bone Joint Surg Br. 2004 Mar;86(2):301-7

12. Tenenhaus M. The Use of Human Amnion/Chorion Membranes in the Treatment of Burns and Complex Wounds. Annals of Plastic Surgery: 78, S11-S13

13. Tejwani S, Kolari RS, Sangwan VS, Rao GN:Role of amniotic membrane graft for ocular chemical and thermal injuries. Cornea 2007;26:21-26

14. Lee H, Ha SW, Kim JC:A novel application of amniotic membrane in patients with bullous keratopathy. J Korean Med Sci.2006;21:324-28

15. Simpson AHRW,Mills L, Noble B:The role of growth factors and related agents in accelerating fracture healing. J Bone Joint Surg 2006;88B(6):701-05 
16. Ozgenel GY, Filiz G: Effects of human amniotic fluid on peripheral nerve scarring and regeneration in rats. J Neurosurg. 2003 Feb;98(2):371-7

17. Ozgenel GY: The influence of human amniotic fluid on the potential of rabbit ear perichondrial flaps to form cartilage tissue. Br J Plast Surg. 2002 Apr;55(3):246-50.

18. Heiple KG, Goldberg VM, Powell AE, Bos GD, Zika JM:Biology of cancellous bone grafts. Orthop Clin North Am. 1987;18:17985

19. Aslan M, Simşek G,Dayı E:The effect of hyaluronic acid-supplemented bone graft in bone healing:Experimental study in rabbits.Journal of Biomaterials Applications.2006;20:209-20

20. Radomsky ML, Aufdemorte TB,Swain LD,Fox CW: Novel formulation of fibroblast growth factor- 2 and hyaluronan gel accelerates fracture healing in nonhuman primates. J Orthop Res. 1999;17:607-14

21. Eckardt H, Christensen KS,Lind M, Hansen ES, Hall DW, Hvid I. Recombinant human bone morphogenetic protein-2 enhances bone healing in an experimental model of fractures at risk of nonunion. Injury.2005;36:489-94

22. Vishwakarma GK, Khare AK: Amniotic arthroplasty for tuberculosis of the hip. A preliminary clinical study. J Bone Joint Surg Br. 1986 Jan;68(1):68-74

23. Nunamaker DM:Experimental models of fracture repair. Clin Orthop Relat Res. 1998 ;355Supp:56-65

24. Mencucci R, Menchini U, Dei R:Antimicrobial activity of antibiotic-treated amniotic membrane:An in vitro study. Cornea 2006;25:428-31

25. Burgos $\mathrm{H}$ : Angiogenic and growth factors in human amnio-chorion and placenta.Eur J Clin Invest. 1983;13(4):289-96

26. Jackson RA, McDonald MM, Nurcombe V,Little DG,Cool $\mathrm{SM}$ :The use of heparan sulfate to augment fracture repair in a rat fracture model. J Orthop Res. 2006;Apr:636-44

27. Utvag SE, Grundnes O, Reikeras O:Effects of lesion between bone,periosteum and muscle on fracture healing in rats. Acta Orthop Scand. 1998;69(2):177-80 